\title{
POLA PEMBERIAN ASI DAN MAKANAN PENDAMPING ASI TERHADAP GRAFIK PERTUMBUHAN PADA KARTU MENUJU SEHAT (KMS)
}

\section{BREAST FEEDING PATTERNS AND COMPLEMENTARY FEEDING TO GROWTH CHART IN KMS}

\author{
Retno Endah Hariani, Dahlia Indah Amareta, dan Arinda Lironika Suryana * \\ Jurusan Kesehatan Politeknik Negeri Jember \\ email : retno_endah2000@yahoo.com
}

\begin{abstract}
Optimal infant growth require adequate nutritional support. Breast Feeding and Complementary feeding can meet all nutritional requirements needed for the baby to grow and develop. Growth in the initial period will determine the growth and development as adults. Monitoring the baby's growth can be observed from the growth chart in KMS. This study aimed to analyze the relationship between breastfeeding and complementary feeding with infant growth chart in KMS. This research is analytic survey with cross sectional study. The sample consisted of 130 baby and their mothers, aged 9-11 months, and visiting health centers Sukorejo Jember. Sampling technique used is purposive sampling. The collection of data patterns of breastfeeding and complementary feeding is done through a method of interviews and questionnaires. Infant growth charts were measured by using Form KMS. Data were analyzed with Spearman Rank. The results showed that the majority of breast feeding patterns enough $(50.8 \%)$, the pattern of giving both breast milk $(56.2 \%)$ and infant growth chart on normal KMS (42.3\%). Statistically significant correlation between patterns of breastfeeding $(\mathrm{p}=0.000)$ and MP-ASI $(\mathrm{p}=0.000)$ with a baby growth chart on KMS.
\end{abstract}

Keyword : Breast Feeding Pattern, Complementary Feeding Pattern, Growth Chart, KMS

\begin{abstract}
ABSTRAK
Pertumbuhan bayi yang optimal memerlukan dukungan nutrisi yang adekuat. Air Susu Ibu dan Makanan Pendamping ASI dapat memenuhi semua kebutuhan zat gizi bayi yang diperlukan untuk proses tumbuh dan berkembang. Pertumbuhan pada periode awal sangat menentukan pertumbuhan dan perkembangan saat dewasa. Pemantauan pertumbuhan bayi dapat diamati dari grafik pertumbuhan pada Kartu Menuju Sehat (KMS). Penelitian ini bertujuan untuk menganalisis hubungan pola pemberian ASI dan MP-ASI dengan grafik pertumbuhan bayi pada Kartu Menuju Sehat (KMS). Penelitian ini merupakan penelitian survey analitik dengan rancangan cross sectional study. Sampel penelitian terdiri dari 130 orang bayi beserta ibunya, bayi berusia antara 9-11 bulan, dan yang mengunjungi Puskesmas Sukorejo Jember. Teknik sampling yang digunakan yaitu purposive sampling. Pengumpulan data pola pemberian ASI dan MP-ASI dilakukan melalui metode wawancara dan pengisian kuesioner. Grafik pertumbuhan bayi diukur dengan menggunakan Formulir Kartu Menuju Sehat (KMS). Data dianalisis dengan uji korelasi Spearman Rank. Hasil penelitian menunjukkan bahwa sebagian besar pola pemberian ASI cukup $(50,8 \%)$, pola pemberian MP-ASI baik $(56,2 \%)$ dan grafik pertumbuhan bayi pada KMS normal $(42,3 \%)$. Secara statistik terdapat hubungan yang signifikan antara pola pemberian ASI $(\mathrm{p}=0,000)$ dan MP-ASI $(\mathrm{p}=0,000)$ dengan grafik pertumbuhan bayi pada KMS (Kartu Menuju Sehat).
\end{abstract}

Kata Kunci : Pemberian ASI, Pemberian MP-ASI, Grafik Pertumbuhan, KMS 
Retno Endah H, Dahlia Indah dan Arinda Lironika S, Pola Pemberian Asi Dan Makanan Pendamping ASI Terhadap Grafik Pertumbuhan Pada Kartu Menuju Sehat (KMS)

\section{PENDAHULUAN}

Pertumbuhan (growth) adalah perubahan yang bersifat kuantitatif yaitu bertambahnya jumlah, ukuran, dimensi pada tingkat sel, organ maupun individu. Anak tidak hanya bertambah besar secara fisik tetapi ukuran dan juga struktur organ-organ tubuh dan otak (Soetjiningsih, 2013).

Keadaan yang sering mempengaruhi awal tumbuh kembang adalah nutrisi. Setiap bayi harus mendapatkan ASI untuk memnuhi kebutuhan gizi bayi. Air Susu Ibu adalah cairan biologis kompleks yang mengandung semua zat gizi yang diperlukan untuk pertumbuhan fisik bayi. ASI disesuaikan dengan keperluan, laju pertumbuhan bayi, dan kebiasaannya menyusu (Sekartini \& Tikoalu, 2013). Oleh karena itu, ASI merupakan makanan bayi terbaik untuk tumbuh dan berkembang. Selain kandungan gizi ASI yang lengkap, dengan menyusu maka bayi juga mendapat stimuli sensori yang komprehensif (taktil, penciuman, pendengaran, kehangatan dan kasih sayang) dari ibunya. Selain ASI, anak juga harus mendapat asupan gizi seimbang untuk memenuhi kebutuhan tumbuh kembang optimal (Soetjiningsih, 2013).

Makanan pertama yang baik untuk bayi hanya ASI, tanpa disertai pemberian Makanan Pendamping ASI selama usia 0-6 bulan. ASI harus menjadi makanan utama selama tahun pertama bayi dan menjadi makanan penting selama tahun kedua. ASI mengandung faktor-faktor anti infeksi yang tidak dapat diberikan oleh makanan lain (Rosidah, 2008). Makanan tambahan bayi sebaiknya diberikan sesuai dengan maturitas saluran pencernaan bayi dan sesuai kebutuhan (Narendra, dkk, 2008).

Makanan Pendamping Air Susu Ibu (MPASI) adalah makanan atau minuman yang mengandung zat gizi yang diberikan kepada bayi yang berusia lebih dari 6 bulan untuk memenuhi kebutuhan zat gizi selain dari ASI. Hal ini dikarenakan ASI hanya mampu memenuhi duapertiga kebutuhan bayi pada usia 6-9 bulan, dan pada usia 9-12 bulan memenuhi setengah dari kebutuhan bayi (Sekartini \& Tikoalu, 2013).

Hal-hal yang perlu diperhatikan dalam pemberian MP-ASI adalah usia pemberian MPASI, jenis MP-ASI, frekuensi dalam pemberian MP-ASI, porsi pemberian MP-ASI, dan cara pemberian MP-ASI pada tahap awal. Pemberian MP-ASI hanya akan mengurangi nafsu minum bayi dan juga dapat berakibat pada berkurangnya suplai ASI. Negara yang telah maju seperti Eropa atau Amerika, menganjurkan pemberian MP-ASI saat bayi berusia lebih dari 6 bulan karena MP-ASI dianggap dapat menyebabkan kegemukan pada bayi jika diberikan pada usia yang terlalu dini. Penelitian lain, menyatakan bahwa keadaan kurang gizi pada bayi dan anak disebabkan karena keterlambatan pemberian MP-ASI dan ketidaktahuan ibu tentang manfaat, serta cara pemberian MP-ASI yang benar (Depkes, 2010).

Penelitian retrospektif yang dilakukan di Baltimore-Washington DC terhadap pertumbuhan bayi yang mendapat ASI eksklusif selama 6 bulan atau lebih. Kurva berat badan terhadap umur dan panjang badan terhadap umur dari bayi yang mendapat ASI eksklusif selama 6 bulan tetap berada di atas $\mathrm{P}_{50}$ kurva NCHS. Bayi yang mendapat ASI eksklusif lebih dari 6 bulan, kurva berat badan terhadap umur dan kurva panjang badan terhadap umur berada di atas $\mathrm{P}_{25}$ kurva NCHS sampai bayi berumur 9-10 bulan. Penelitian ini menunjukkan bahwa dalam kondisi yang optimal, ASI eksklusif mendukung pertumbuhan bayi selama 6 bulan pertama atau lebih (Sekartini \& Tikoalu, 2013).

KMS (Kartu Menuju Sehat) adalah alat yang penting untuk memantau tumbuh kembang anak. Aktifitas pemantauan tidak hanya menimbang dan mencatat saja melainkan juga harus menginterpretasikan tumbuh kembang anak kepada ibunya, sehingga ibu memahami bahwa pertumbuhan anak dapat diamati dengan cara menimbang teratur setiap bulan. KMS yang ada di Indonesia pada saat ini berdasarkan Baku WHO 2005 (WHO child Growth Standard 2005/WHOMGRS/WHO Anthro 2005). KMS dapat menggambarkan pola pertumbuhan anak yang teratur dan koheren (Soetjiningsih, 2013). Dengan dasar pemikiran tersebut diatas, maka perlu dilakukan penelitian untuk menganalisis "Pola Pemberian ASI dan MP ASI terhadap Grafik Pertumbuhan Bayi Pada Kartu Menuju Sehat"

\section{METODOLOGI}

Jenis penelitian ini adalah penelitian survei analitik dengan desain penelitian Cross Sectional Study. Pada survey ini peneliti akan melakukan pendekatan atau pengukuran terhadap sampel disaat yang hampir bersamaan untuk mengetahui faktor risiko pada kelompok sampel (Kuntoro, 2010).

Penelitian ini dilakukan di wilayah kerja Puskesmas Sukorejo Jember pada Bulan September 2015. Sampel adalah bayi usia 9-11 bulan sebanyak 130 orang yang memenuhi kriteria inklusi yaitu datang berkunjung ke posyandu saat penelitian, KMS terisi dalam 3 bulan terakhir dan 
mendapat ASI dan MP-ASI. Sampel diambil dengan metode purposive sampling.

Variabel dependen penelitian adalah grafik pertumbuhan pada KMS. Sedangkan variabel independen penelitian adalah pola pemberian ASI (teknik menyusui, frekuensi menyusui, lama menyusui dan pemberian ASI eksklusif) dan pola pemberian MP-ASI (teknik pemberian MP-ASI, umur pemberian MP-ASI, frekuensi pemberian MP-ASI, jenis MP-ASI).

Instrumen yang dipakai dalam penelitian ini menggunakan lembar kuesioner pola pemberian ASI dan MP-ASI dan formulir Kartu Menuju Sehat (KMS) untuk grafik pertumbuhan. Pengolahan data menggunakan SPSS versi16 for window. Data dianalisis dengan uji bivariat menggunakan uji korelasi Spearman Rank Test dengan derajat kemaknaan $\mathrm{p}<0,005$

\section{HASIL DAN PEMBAHASAN}

\section{Karakteristik Responden}

Penelitian ini melibatkan 130 bayi beserta ibu sebagai responden. Jumlah responden yang berjenis kelamin laki-laki dan perempuan adalah sama. Sebagian besar bayi berumur 11 bulan. Karakteristik responden dalam penelitian ini dilihat berdasarkan umur dan jenis kelamin bayi serta tingkat pendidikan dan pekerjaan ibu. Distribusi frekuensi dari karakteristik responden ditujukkan dalam tabel 1 .

Tabel 1. Distribusi Karakteristik Responden

\begin{tabular}{|l|c|c|}
\hline \multicolumn{1}{|c|}{$\begin{array}{c}\text { Karakteristik } \\
\text { Responden }\end{array}$} & \multicolumn{2}{c|}{ Distribusi } \\
Frekuensi (n=130)
\end{tabular}

Secara teori kurangnya pemberian ASI eksklusif juga dapat dipengaruhi dari perilaku seseorang terhadap objek kesehatan, ada tidaknya dukungan dari keluarga, pendidikan ibu, dan tidak tersedianya informasi yang memadai tentang pentingnya ASI ekslusif (Notoatmodjo, 2010). Hasil penelitian menunjukkan bahwa tingkat pendidikan ibu yang paling banyak adalah tamat SD $(56,9 \%)$ dan tingkat pendidikan paling sedikit adalah lulus S1 (1,5\%). Tinggi rendahnya tingkat pendidikan ibu belum tentu berkaitan dengan kurangnya pengetahuan ibu. Berdasarkan hasil wawancara saat penelitian diketahui beberapa hal yang sering dilakukan oleh responden untuk memperoleh pengetahuan tentang ASI dan MPASI, seperti aktif mencari informasi melalui internet, televisi dan informasi mengenai pola pemberian ASI dan MP-ASI melalui membaca di buku Kartu anak dan Ibu (KIA), bertanya kepada orang tua ibu dan berdiskusi antar sesama orang tua tentang pengalaman dalam memberikan ASI dan MP-ASI pada bayi, sehingga hal tersebut kemungkinan besar menjadi penyebab tidak berdampaknya tingkat pendidikan terhadap pengetahuan responden.

Jika ditinjau dari jenis pekerjaan, sebagian besar responden berstatus sebagai ibu rumah tangga $(90,8 \%)$ dan sisanya $(9,2 \%)$ bekerja baik sebagai pegawai swasta, wiraswasta maupun petani. Banyaknya ibu yang berstatus sebagai seorang ibu rumah tangga berdampak positif bagi tumbuh kembang bayi karena ibu akan memiliki banyak waktu panjang untuk merawat bayinya sehingga ibu dapat memberikan ASI secara maksimal kepada bayinya. Hanya beberapa Negara yang dapat menjamin secara hukum pemberian ASI oleh ibu yang bekerja sehingga ibu dapat meninggalkan pekerjaan mereka dengan mengambil waktu pendek untuk menyusui (Putri, 2008).

Ibu yang lebih pendek memberikan ASI ekslusif, sering dijumpai di negara berkembang. Penghentian pemberian ASI di Indonesia, sering didasarkan berbagai alasan seperti hamil lagi, anak cukup umur untuk mendapatkan makanan tambahan, payudara sakit, air susu tidak keluar, lingkungan sosial budaya, ibu bekerja, terpengaruh makanan penganti ASI, dan sebagainya (Arifin, 2008).

Distribusi frekuensi dari pola pemberian ASI, pola pemberian MP-ASI dan grafik pertumbuhan bayi ditunjukan pada pada tabel 2 .

Tabel 2 Distribusi Frekuensi Pola Pemberian ASI, MP-ASI dan Grafik Pertumbuhan

\begin{tabular}{|c|c|}
\hline Variabel & $\begin{array}{c}\text { Distribusi Frekuensi } \\
(\mathbf{n}=130)\end{array}$ \\
\hline
\end{tabular}


Retno Endah H, Dahlia Indah dan Arinda Lironika S, Pola Pemberian Asi Dan Makanan Pendamping ASI Terhadap Grafik Pertumbuhan Pada Kartu Menuju Sehat (KMS)

\begin{tabular}{|c|c|c|}
\hline & & \\
\hline & $\mathbf{n}$ & $\%$ \\
\hline \multicolumn{3}{|l|}{ Pola Pemberian ASI } \\
\hline Baik & 38 & 29,2 \\
\hline Cukup & 66 & 50,8 \\
\hline Kurang & 26 & 20,0 \\
\hline Total & 130 & 100 \\
\hline \multirow[t]{2}{*}{ Variabel } & \multicolumn{2}{|c|}{$\begin{array}{c}\text { Distribusi Frekuensi } \\
(n=130)\end{array}$} \\
\hline & $\mathbf{n}$ & $\%$ \\
\hline \multicolumn{3}{|c|}{$\begin{array}{l}\text { Pola Pemberian MP- } \\
\text { ASI }\end{array}$} \\
\hline Baik & 73 & 56,2 \\
\hline Cukup & 44 & 33,8 \\
\hline Kurang & 13 & 10,0 \\
\hline Total & 130 & 100 \\
\hline \multicolumn{3}{|c|}{ Grafik Pertumbuhan } \\
\hline Tumbuh kejar & 42 & 32,2 \\
\hline Tumbuh normal & 55 & 42,3 \\
\hline $\begin{array}{l}\text { Tumbuh tidak } \\
\text { memadai }\end{array}$ & 30 & 23,1 \\
\hline Tidak tumbuh & 3 & 2,3 \\
\hline Total & 130 & 100 \\
\hline
\end{tabular}

Tabel 2. menunjukkan pola pemberian ASI menunjukkan bahwa sebagian besar responden memberikan ASI yang tergolong cukup yaitu sebanyak 66 orang $(50,8 \%)$. Responden memberikan ASI yang tergolong baik yaitu 38 orang $(29,2 \%)$ dan responden memberikan ASI yang tergolong kurang yaitu 26 orang (20\%).

Pola pemberian MP-ASI menunjukkan bahwa sebagian besar responden memberikan MP-
ASI yang tergolong baik yaitu sebanyak 73 orang $(56,2 \%)$ dan responden memberikan MP-ASI yang tergolong kurang yaitu 13 orang $(10,0 \%)$.

Pertumbuhan bayi berdasarkan grafik Kartu Menuju Sehat (KMS) menurut indeks berat badan menunjukkan bahwa sebagian besar bayi tergolong dalam pertumbuhan normal yaitu sebanyak 55 orang $(42,3 \%)$ sedangan bayi yang pertumbuhannya tergolong tidak tumbuh yaitu sebanyak 3 orang $(2,3 \%)$.

Kartu Menuju Sehat (KMS) merupakan kartu yang memuat grafik pertumbuhan normal anak yang berdasarkan indeks antropometri berat badan menurut umur. Grafik pertumbuhan KMS dibuat berdasarkan indeks antropometri berat badan menurut umur. Selain sebagai alat untuk memantau pertumbuhan bayi KMS juga digunakan sebagai catatan pelayanan kesehatan bayi dan sebagai alat edukasi. Menurut Depkes RI (2010) grafik pertumbuhan yang terdapat pada KMS digunakan untuk memantau pertumbuhan bayi setiap bulannya apakah bayi tumbuh normal atau mengalami gangguan pertumbuhan. Bila grafik berat badan bayi mengikuti grafik pertumbuhan pada KMS artinya anak tumbuh baik, kecil resiko anak untuk mengalami gangguan pertumbuhan. Sebaliknya bila grafik berat badan tidak sesuai dengan grafik pertumbuhan anak kemungkinan beresiko mengalami gangguan pertumbuhan.Dengan KMS gangguan pertumbuhan atau risiko kelebihan gizi dapat diketahui lebih dini, sehingga dapat dilakukan tindakan pencegahan secara lebih cepat dan tepat sebelum masalahnya lebih berat.

Tabel 3. Hubungan Antara Pola Pemberian ASI Dengan Grafik Pertumbuhan Pada KMS

\begin{tabular}{|c|c|c|c|c|c|c|c|c|c|c|c|c|}
\hline \multirow{3}{*}{$\begin{array}{c}\text { Pola } \\
\text { Pemberian } \\
\text { ASI }\end{array}$} & \multicolumn{8}{|c|}{ Grafik Pertumbuhan KMS } & & & \multicolumn{2}{|c|}{ Spearman's Rank } \\
\hline & \multicolumn{2}{|c|}{$\begin{array}{l}\text { Tumbuh } \\
\text { Kejar }\end{array}$} & \multicolumn{2}{|c|}{$\begin{array}{l}\text { Tumbuh } \\
\text { Normal }\end{array}$} & \multicolumn{2}{|c|}{$\begin{array}{c}\text { Tumbuh } \\
\text { Tidak } \\
\text { Memadai }\end{array}$} & \multicolumn{2}{|c|}{$\begin{array}{c}\text { Tidak } \\
\text { Tumbuh }\end{array}$} & \multicolumn{2}{|c|}{ Total } & $\mathrm{P}$ & $r$ \\
\hline & $\mathrm{n}$ & $\%$ & $\mathrm{n}$ & $\%$ & $\mathrm{n}$ & $\%$ & $\mathrm{n}$ & $\%$ & $\mathrm{n}$ & $\%$ & & \\
\hline Baik & 28 & 21,5 & 9 & 6,92 & 0 & 0 & 0 & 0 & 37 & 28,4 & & \\
\hline Cukup & 14 & 10,7 & 40 & 30,7 & 12 & 9,23 & 1 & 0,76 & 67 & 51,5 & $0,000^{*}$ & 0,693 \\
\hline Kurang & 0 & 0 & 6 & 4,61 & 18 & 13,8 & 2 & 1,53 & 26 & 20 & & \\
\hline Total & 42 & 32,3 & 55 & 42,3 & 30 & 23 & 3 & 2,3 & 130 & 100 & & \\
\hline
\end{tabular}

Keterangan : * Korelasi signifikan pada $\alpha 0,005$

Berdasarkan Tabel 3 diatas diketahui bahwa bayi yang pola pemberian ASI-nya cukup, sebagian besar $(30,7 \%)$ memiliki grafik pertumbuhan normal dan hanya $0,76 \%$ yang grafik pertumbuhannya tergolong tidak tumbuh. Setelah dianalisis dengan uji korelasi spearman's rank diperoleh nilai $\mathrm{p}=0,000(\mathrm{p}<\alpha)$ maka dapat disimpulkan bahwa terdapat hubungan yang signifikan antara pola pemberian ASI dengan grafik pertumbuhan bayi pada KMS. Hasil penelitian menunjukkan $r=0,693$ dengan arah korelasi searah (positif) kuat yang berarti semakin baik pola pemberian ASI maka semakin baik pula grafik pertumbuhan KMS bayi.

Terdapatnya hubungan pola pemberian ASI dengan grafik pertumbuhan bayi yaitu cukupnya pemberian ASI, yang berarti bahwa perilaku ibu positif terhadap teknik pemberian ASI, frekuensi 
pemberian ASI, lama atau durasi dalam pemberian ASI dan pemberian ASI eksklusif. Pengetahuan yang dimiliki ibu melandasi perilaku ibu dalam pemberian ASI kepada bayi. Pemberian ASI akan mempengaruhi asupan ASI dan berdampak pada peningkatan grafik pertumbuhan bayi. Hal ini sesuai dengan teori Bloom yang menyatakan bahwa, pola pemberian ASI oleh responden tersebut kemungkinan, didukung dengan pemahaman mengenai ASI dan sikap yang baik sehingga grafik pertumbuhan bayi baik.
Hasil penelitian ini sejalan dengan penelitian yang dilakukan oleh Ridzal dkk (2013) di dapatkan hasil dari uji statistik diperoleh nilai $\mathrm{p}=0,047(\mathrm{p}<0,05)$ dimana derajat kemaknaan $\alpha=$ 0,05 secara statistik dapat di interpretasikan bahwa, terdapat hubungan yang signifikan antara pola pemberian ASI berdasarkan pemberian lama pemberian ASI dengan status gizi pada anak usia 6-23 bulan di wilayah pesisir Kecamatan Tallo Kota Makasar.

Tabel 4. Hubungan Antara Pola Pemberian MP-ASI Dengan Grafik Pertumbuhan Pada KMS

\begin{tabular}{|c|c|c|c|c|c|c|c|c|c|c|c|c|}
\hline \multirow{3}{*}{$\begin{array}{c}\text { Pola } \\
\text { Pemberian } \\
\text { MP-ASI }\end{array}$} & \multicolumn{8}{|c|}{ Grafik pertumbuhan KMS } & \multirow{2}{*}{\multicolumn{2}{|c|}{ Total }} & \multicolumn{2}{|c|}{ Spearman's Rank } \\
\hline & \multicolumn{2}{|c|}{$\begin{array}{l}\text { Tumbuh } \\
\text { Kejar }\end{array}$} & \multicolumn{2}{|c|}{$\begin{array}{l}\text { Tumbuh } \\
\text { Normal }\end{array}$} & \multicolumn{2}{|c|}{$\begin{array}{c}\text { Tumbuh } \\
\text { Tidak } \\
\text { Memadai }\end{array}$} & \multicolumn{2}{|c|}{$\begin{array}{c}\text { Tidak } \\
\text { Tumbuh }\end{array}$} & & & $\mathbf{p}$ & $\mathbf{r}$ \\
\hline & $\mathrm{n}$ & $\%$ & $\mathrm{n}$ & $\%$ & $\mathrm{n}$ & $\%$ & $\mathrm{n}$ & $\%$ & $\mathrm{n}$ & $\%$ & \multirow{5}{*}{$0,000 *$} & \multirow{5}{*}{0,751} \\
\hline Baik & 40 & 30,76 & 28 & 21,5 & 2 & 1,5 & 0 & 0 & 70 & 53,8 & & \\
\hline Cukup & 2 & 1,53 & 27 & 20,7 & 15 & 11,5 & 2 & 1,5 & 46 & 35,3 & & \\
\hline Kurang & 0 & 0 & 0 & 0 & 13 & 10 & 1 & 0,76 & 14 & 10,7 & & \\
\hline Total & 42 & 32,3 & 55 & 42,3 & 30 & 23 & 3 & 2,3 & 130 & 100 & & \\
\hline
\end{tabular}

* Korelasi signifikan pada $\alpha 0,005$

Tabel 4 menunjukkan bahwa mayoritas bayi memiliki pola pemberian MP-ASI baik $(53,8 \%)$ dan sebagian kecil pola pemberian MPASI kurang $(10,7 \%)$. Hanya ada $1,5 \%$ bayi yang pola pemberian MP-ASI nya baik tapi grafik pertumbuhannya menunjukkan pertumbuhan yang tidak memadai dan $30,76 \%$ bayi dengan grafik pertumbuhan dengan status tumbuh kejar. Sebagian besar bayi yang grafik pertumbuhannya normal $(20,7 \%)$ memperoleh pemberian ASI yang cukup.

Hubungan pola pemberian MP-ASI dengan grafik pertumbuhan terlihat dari hasil tabulasi silang yang menunjukkan, bahwa pola pemberian MP-ASI yang baik akan diikuti oleh grafik pertumbuhan yang sangat baik. Hasil analisis korelasi spearman's rank menunjukkan terdapat hubungan yang signifikan $\rho=0,000(\mathrm{p}<\alpha)$ antara pola pemberian MP-ASI dengan grafik pertumbuhan bayi dengan arah korelasi searah positif kuat $(r=0,751)$. Semakin baik pola pemberian MP-ASI maka semakin baik pula grafik pertumbuhan KMS bayi.

Hasil penelitian ini sesuai dengan hasil penelitian sebelumnya (Dewi dkk, 2010) yang menyatakan bahwa ada hubungan yang cukup kuat antara pola pemberian MP-ASI dengan status gizi bayi usia 6-12 bulan di Desa Kaliori Kecamatan Kalibagor Kabupaten Banyumas. Penelitian Lestari, 2012 mendapatkan data bayi yang diberi MP-ASI sesuai jadwal memiliki status gizi lebih baik jika dibandingkan dengan bayi yang diberi MP-ASI dini. Jadi ada hubungan yang bermakna antara usia pemberian MP-ASI dengan status gizi (indeks BB/TB) dengan nilai $\mathrm{p}=0,001 \quad(\mathrm{p}<0,05)$. Hal ini karena pada saat bayi usia lebih dari 6 bulan sistem pencernaannya sudah relatif sempurna dan siap menerima makanan padat.

Pola pemberian MP-ASI baik berarti perilaku ibu positif terhadap kapan waktu yang tepat untuk memberikan makanan pendamping ASI, teknik pemberian makanan pendamping ASI, frekuensi pemberian makanan pendamping ASI dan bentuk makanan pendamping ASI. Pemberian MP-ASI akan mempengaruhi asupan gizi bayi dan akan berdampak pada peningkatan grafik pertumbuhan bayi. Hal ini sesuai dengan teori Bloom yang menyatakan bahwa, pola pemberian MP-ASI responden tersebut kemungkinan didukung dengan pemahaman mengenai MP-ASI dan sikap yang baik sehingga grafik pertumbuhan bayi baik.

Konsumsi pangan yang tidak cukup energi biasanya juga kurang dalam satu atau lebih zat gizi esensial lainnya. Konsumsi energi dan protein yang kurang selama jangka waktu tertentu akan menyebabkan gizi kurang, sehingga untuk menjamin pertumbuhan, perkembangan dan kesehatan bayi maka perlu asupan gizi yang cukup (Dewi dkk, 2010). Apabila makanan pendamping ASI tidak diberikan pada waktu, bentuk dan jumlah yang tepat, penurunan grafik pertumbuhan akan berlangsung terus bahkan dapat mengakibatkan kondisi yang lebih berat yakni grafik pertumbuhan bayi berada pada garis merah (Dewi dkk, 2010). 
Retno Endah H, Dahlia Indah dan Arinda Lironika S, Pola Pemberian Asi Dan Makanan Pendamping ASI Terhadap Grafik Pertumbuhan Pada Kartu Menuju Sehat (KMS)

Studi-studi tentang status gizi menunjukkan adanya hubungan antara pola pemberian makanan pendamping ASI dan grafik pertumbuhan pada balita. Sesuai dengan pendapat Moehyi (1998) dalam Septiani, dkk (2010) yang menyatakan bahwa, pemberian makanan yang kurang tepat dapat menyebabkan terjadinya grafik pertumbuhan yang tidak sesuai. Secara teoritis pola pemberian MP-ASI dipengaruhi oleh faktor ibu, karena ibulah yang sangat berperan dalam mengatur konsumsi anak, yang kemudian akan berpengaruh terhadap grafik pertumbuhan bayi.

\section{KESIMPULAN}

Dari hasil penelitian dapat disimpulkan bahwa terdapat hubungan yang bermakna antara pola pemberian ASI $(p=0,000, p<\alpha)$ dan MP ASI $(\mathrm{p}=0,000, \mathrm{p}<\alpha)$ terhadap grafik pertumbuhan pada Kartu Menuju Sehat. Hubungan tersebut menunjukkan jika pola pemberian ASI dan MPASI baik makan grafik pertumbuhan bayi usia 911 bulan pada KMS (Kartu Menuju Sehat) menunjukkan pertumbuhan normal.

Penelitian ini hanya meneliti terbatas pada indeks $\mathrm{BB} / \mathrm{U}$ pada KMS sebagai parameter pertumbuhan dan hanya menjabarkan pola pemberian ASI dan MP-ASI secara garis besar. Pada penelitian selanjutnya perlu diperbaiki dengan menggunakan parameter pertumbuhan lain misalnya TB/U atau BB/TB pada Form CDC dan merinci lebih dalam aspek-aspek pola pemberian ASI dan MP-ASI

\section{DAFTAR PUSTAKA}

Departemen Kesehatan RI. 2010. Peraturan Menteri Kesehatan Republik Indonesia tentang penggunaan Kartu Menuju Sehat (KMS) Bagi Balita. Jakarta.

Dewi, dkk. 2010. Hubungan Pola Pemberian Makanan Pendamping ASI (MP-ASI) Dengan Status Gizi Balita Usia 6-12 Bulan Di Desa Kaliori Kecamatan Kalibagor Kabupaten Banyumas. Jurnal Ilmiah
Kebidanan Vol 2 No 1Edisi Juni 2011, p: 97110

Lestari, Mahaputri dkk. 2014. Hubungan Pemberian Makanan Pendamping ASI Dengan Status Gizi Anak Usia 1-3 Tahun di Kota Padang. Jurnal Kesehatan Andalas Vol 3 No 2(2014), p:188-190

Notoatmodjo, Soekidjo. 2010. Metodologi Penelitian Kesehatan. Jakarta: PT. Rineka Cipta

Kuntoro. 2010. Metode Sampling Dan Penentuan Besar Sampel. Surabaya: Pustaka Melati.

Putri. 2008. Faktor-Faktor Yang Mempengaruhi Perilaku Menyusui Di Wilayah Kerja Puskesmas Pancoran Mas, Depok, Tahun 2008. Universitas Indonesia

Sakti, dkk. 2013. Hubungan Pola Pemberian MPASI dengan Status Gizi Anak Usia 6-23 Bulan di Wilayah Pesisir KecamatanTallo Kota Makasar. Makasar : Politeknik Kesehatan Kemenkes.

Sekartini, R., \& Tikoalu, J. L. (2013). Buku Bedah ASI IDAI. Jakarta: IDAI.

Septiana, dkk. 2010. Hubungan Antara Pola Pemberian Makanan Pendamping ASI (MPASI) Dan Status Gizi Balita Usia 6-24 Bulan Di Wilayah Kerja Puskesmas Gedongtengen. Yogyakarta : Universitas Ahmad Dahlan. Yogyakarta.

Soetjiningsih. (2013). Konsep Dasar Tumbuh Kembang Anak. Dalam Soetjiningsih, \& I. G. Ranuh, Tumbuh Kembang Anak Edisi 2 (hal. 2-15). Jakarta: EGC.

Ridzal, dkk. 2013. Hubungan pola Pemberian ASI dengan Status Gizi Anak Usia 6-23 Bulan di Wilayah Pesisir Kecamatan Tallo Kota MakasarTahun 2013. Universitas Hasanuddin.

Rosidah. 2008. Pemberian Kelengkapan Makanan Dan Pertumbuhan Anak Balita Usia 1-3 Tahun DI Posyandu GarudaKecamatan Herlang Kabupaten Bulukumba. Journal of Pediatric Nursing 